\title{
MALEFICENT: REIMAGINING “THE SLEEPING BEAUTY” WITH A POST- MODERNIST PERSPECTIVE
}

\author{
Mehwish Ali Khan \\ Ms. Ph.D. Scholar., Quaid-i-Azam University, Pakistan, mahwishalisbkwu@hotmail.com
}

\begin{abstract}
The goal of the present project is to highlight the postmodernist perspective of the fairy tale themes in the movie Maleficent (2014) through Intertextuality. The present study aims to highlight the rejection of authority by the Contemporary American Fairy Tale movie makers. Postmodernism is an era where "Meta-Narratives" are challenged and everything is being observed through a lens different from the past. Movie creators of postmodern era have reinterpreted the original fairy tales in ways that fit contemporary norms and circumstances. Movie creators represent the old texts of fairy tales but have changed the title, plot and role of characters, e.g. in Maleficent, the antagonist of "Sleeping Beauty" now owns the title of the story, and she also shares her part of the story, which was previously unknown.

The researcher used the eight elements that Kevin Paul Smith has mentioned in his book Post Modern Fairy tales, Folk Loric Intertexts in Contemporary Fiction. The fifth element particularly, i.e. "revision", makes the claim of the researcher valid that Postmodernists have rejected totality and grand narratives, they have opened new dimensions to the old stories. The story here is given a new spin and the changes made in the story of "Sleeping Beauty" are according to the norms of today, e.g. the women in the movie i.e. "Aurora", the Princess and Maleficent the Witch are given a prominent position and a voice to speak their point of view, previously they were known through the eyes of other characters only. These results show a change in perspectives and in the way things are now being looked at. Fairy tales are the movies that are easily accessible to our children, further study on this theme can help understand the society of today, the postmodernist society.
\end{abstract}

Keywords: Intertextuality, Postmodernism, Fairytales.

\section{INTRODUCTION}

Maleficent released in 2014, is a fairytale written by screenplay writer, Linda Woolverton who takes a postmodernist approach and changes the original version of the story engraved in everyone's mind. The story here is retold with a postmodernist approach, an approach where the old narratives are challenged and new versions are brought forward. The reality, as propagated by scholars of Postmodernism, is based on knowledge, which is further related to power but, Linda Woolverton by taking a postmodernist approach tries to break the dominance of knowledge created in reader/ audiences' mind. The researcher here takes postmodernist characteristics and analyzes Maleficent. 


\section{LITERATURE REVIEW}

Postmodernism is a movement that challenges the political, literary, and, social authority. It rejects the "MetaNarratives", the narratives of the famous authors and brings forward every kind of point of view, whether important or unimportant (Barry, 2008, p.86). It propagates a pluralist point of view. Postmodernism is all about representation, it deals with ways of representing reality and what is actually considered real. $J A$ Cuddon pens postmodernism in his Dictionary of literary terms and literary theory as "an eclectic approach, (and a liking for) aleatory writing and for parody and pastiche" (1999, p.553).

Postmodern literature as a whole is hard to define and there is little consensus on the exact characteristics, scope, and the importance of postmodern literature. Postmodernist literature is a part of the socio-cultural and historical development and it portrays modern life and culture in a specific way (Sharma, 2011, p. 190). It shows the struggle of human beings in the hypocritical society. Postmodernist writers often point to early novels and story collections as inspiration for their experiments with narrative and structure. In postmodernist literature originality and authenticity is challenged and mocked. Postmodern literature does not focus on subjectivity, instead, it focuses on radical plurality and relativism which completely negates authority in perceiving the outer world, and it distrusts the unified truth, the eternal truths about the world (Crews,1999, p. 29).

Jean Francis Lyotard in his essay "Answering the Question: What is postmodernism" brings forth the famous definition of postmodernism that it is "incredulity towards metanarratives". He is of the view that the authoritative approaches, these "Grand Narratives", are only to curb the differences, opposition, and plurality. Whereas postmodernity deconstructs "the idea of a unitary end of history and of subject" (1984, p.74).

Postmodernist writers highlight a decentered concept of life, they don't believe in isolated works of art, instead, most of the work is intertextualized, which means one text is related to another, it can be a direct reference or an extended discussion of the previous work. (Sharma, 2011, p.191)

Barthes is of the view that original meaning of word text is " a tissue, a woven fabric" thus revealing that text is not a line of words which reveals a single authoritative meaning but it is an amalgamation of a variety of meanings based on different writings which blend and clash together. All these meanings are drawn from various centers of culture, only literary meaning can never create a stability because of the intertextual nature, the reader always makes new textual relations. (1977, p.159)

According to Anton Pokrivčák, and Pokrivcakova,

"The most obvious techniques to build intertextual networks of literary texts include direct reference, allusion, quotation, echo, plagiarism, collage, mosaics, palimpsest, and others" (2006, p.20). Pokrivčák and Pokrivcakova continue by saying that "Intertextual networks are also generated by cultural discourses and the media". One of the most important aspects of a postmodern literary work closely connected to metafiction is, however, intertextuality" (2006, p.20)

The term intertextuality was coined by the Bulgarian poststructuralist theorist Julia Kristeva in her article Word Dialogue and Novel, which was published in 1966. Kristeva owes much to Mikhail Bakhtin for coining and developing the concept of intertextuality. His works gave her the idea for the definition of intertextuality. Due to her familiarity with the Russian language and culture, she developed the theoretical grounds of intertextuality. Bakhtin's concept of dialogism introduced in his collection of four essays related to language and novel explain that it is a connection between source text and dialogic text, this connection is unrestricted and limitless, and that there is no single authorial meaning in the text because a word does not have affixed meaning but actually words are a chain of connectivity with all the related words of past and future. The word in language... assert scholars... is half someones else. (1986.p. 35)

Postmodernism places great emphasis on radical plurality and relativism. Postmodern writers use Intertextuality as a tool to play and turn the original meaning of the texts upside down. They break the authority and destabilize the hierarchies to rearrange the meaning. The intertexts, undergoing the dialogical process, help the reader to look at the text with a new understanding; this makes them question the old authoritative ideas, playing a part in creating a new insight and changing fixed meanings. (Yaqoob, 2012, p. 478)

Intertextuality by involving the texts in dialogues creates the text as the mosaic of references or quotations from other texts, a text is an open system which can never be isolated but moves back and forth with other texts and questions the authority of older texts, it allows for the re-vision and adoption of older texts to suit new situations and meanings. Outmoded assumptions are criticized through its use. Intertextuality, due to its nature calls attention to the act of story- telling, through which the reader /audience gets to know how the author is changing the earlier story often called metafiction, which means fiction about fiction. Intertextuality 
is a reflection on metafiction, it highlights the fact that meaning is not final or permanent but rather a construct, a thread linked to other threads. (Baer, 2005, pp. 145-152) Intertextuality plays an important role in highlighting the postmodernist aspects present in the contemporary American fairy tale movies. The original versions of fairy tales, where heroines are passive, the minor characters are silent and the royalty is the only class present, are altered according to the vision of postmodernists. These alterations are traced through analysis of intertextual elements.

Fairytale belongs to folk Literature and is considered to be part of oral tradition. In written form, the fairy tales tend to be narratives in prose form recording the fortunes and misfortunes of heroes or heroines, who in the end always "live happily ever after". Supernatural elements, for instance, fairies, magic spells are all present in it. (Cuddon, 2000, p. 302)

Stephon Benson in his book "Contemporary Fiction and the Fairy Tale" explains that "postmodern novelists who embed fairy tale "intertexts" generally revise or deconstruct them, using irony, parody and sometimes satire of these "intertexts" alongside the tales original character types, themes, motifs, and images, often turning fairy tale plots upside down, reversing outcomes and using unreliable narrators, anti- heroes/heroines and magical realism, the texts generally exist in a romance mode and may still depict transformation...". (2008. p. 99)

Bacchilega makes an excellent case for taking a postmodern approach to what she calls postmodern fairy tales, or new readings of fairy tales, including "literary texts, cartoons, movies, musicals, [and] soap operas," that exhibit ideologically charged self-reflexivity and disseminate parody and performative multiple versions $(1999,1-26)$

A recent research, on the changed roles of fairy tale characters presented in Media, discusses that Magical helpers are still present in genres that draw upon fairy tales, such as fantasy novels and films and the contemporary American understanding toward supernatural improvements highlights some of the changes made to folktale helpers (Jorgenson,2007, pp.216-217) The roles in the recent texts have changed their positions. The fairy godmothers who were typical helpers in past now take on new roles, at times they are even challenging the protagonist. In the case of Maleficent, the evil fairy has been turned into a fairy godmother and the fairy godmothers who in the past were the caretakers of princess Aurora are not only physically turned into "Lilliputian" figures but metaphorically also they turn into helpless, talkative and ignorant pixies.

The contemporary fairy tales are altered based not on eternal truths but truths constructed through relativity. The theory of intertextuality is helpful to bring forth the motive behind these alterations. Such an example of intertextuality is seen in one of the most celebrated fairy tales of times. "Sleeping Beauty" produced as a very famous American Movie known as Maleficent. If the origin of this tale is traced it goes back to Italian writer Giambattista Basile's "Sun, Moon, and Talia" (1636) in a collection known as "The Pentamerone". In Basile's story Talia (whose name derives from the Greek word Thaleia, meaning "the blossoming one") gets a tiny piece of flax under her fingernail and falls down dead. The king who discovers Talia in an abandoned castle is already married, but he is so overcome with desire for her that he "plucks from her the fruits of love" while she is still asleep. Talia is awakened from her deep sleep when one of the two infants to which she gives birth, exactly nine months after the king's visit, sucks the piece of flax from her finger. When the king's wife learns about Talia and her two children, Sun and Moon, she orders their deaths, but she herself burns in the fire she prepares for Talia, and the others live happily ever. (Tatar, 2002, p 95)

It was later adopted and a little altered In European Literature by a seventeenth-century French writer, Charles Perrault in 1696. Charles Perrault's Fairytales "Contes de ma mere l'Oye" translated into English by Robert Samber in 1729 hold a prominent place. It has the story of "Sleeping Beauty in the Wood" which is a story of a king and queen who after having a long awaited baby girl, fall into a deep gloom when she is cursed by a fairy Maleficent, the name Maleficent is given to the fairy in the later versions, who was overlooked on the baby's christening. Seven other fairies were invited and had golden caskets made for them. This in return makes Maleficent angry, she takes revenge by cursing the child that she will prick her finger on a spindle and will die whereas the seventh fairy who had not blessed the child yet comes out, although she cannot undo the spell but she gives her blessing that she will not die but will sleep for hundred years and will be awakened by a prince's true love kiss. (The Sleeping Beauty, 1873)

The Grimms' story of Sleeping Beauty is considered a shortened version of writer Giambattista Basile's "Sun, Moon, and Talia" (1636) and Charles Perrault's "Sleeping Beauty in the Wood" (1697). The Grimms' chronicle of Sleeping Beauty turned out more appealing than Basile's story and Perrault's tale. Sleeping Beauty is a typical conventional girl whose only quality was that she is beautiful and fair by heart, bravery was a trait which was attributed only to the heroes of the story, those prince's, only whose help could save the princess from every kind of evil and bad luck, Deprived of action, she resembles the impassive Snow 
White, who can do nothing more than lie in wait for Prince Charming. Yet this cliché about fairy-tale heroines ignores the notion that women can also be clever and resourceful and they can liberate themselves from every kind of peril, this patriarchal dominance was engraved very deeply in the fairy tales and it was never questioned, from Basile till the tales entry into Walt Disney's Sleeping Beauty in 1959. Then came the postmodernist traits. (Tatar, 2002, p.96)

In Walt Disney's "Maleficent" the movie makers have taken a villainess and have changed her outlook, she is a protagonist and a villainess at the same time. "Maleficent" is an update of "The Sleeping Beauty". In the new version, the fairy's rage is given a new perspective. There are two children in the movie. One is Stefan, a simple country boy. The other is Maleficent, a sweet little girl. Maleficent and Stefan are friends. The king of the territories neighboring Maleficent goes to war with her and loses, so he declares that whoever can kill her will succeed him as king. Stefan with the hope of becoming a king visits Maleficent to kill her but he doesn't bring himself up to it. So he just cuts her wings, Stefan becomes the king according to the promise. He has a daughter Aurora, who is cursed by Maleficent as revenge. Aurora is sent away from the palace under the care of three fairies so that she remains away from the evil of the curse. They are the same fairies who were in the first version although the number has decreased from seven to three. Their function has also changed from caring responsible fairies to irresponsible, frantic pixies. Aurora instead of them is looked after by Maleficent, who despite giving a statement that she dislikes children takes care of her. The curse on Aurora is that she is pricked by a spindle and will fall asleep all her life unless it is revived by a "true love kiss". Maleficent tries to undo the curse which doesn't happen then she removes all the spindles away from Aurora's reach but Aurora is pricked. Maleficent then tries to bring Princess Philip, a young prince from the neighboring territory, in touch with Aurora so that she is kissed by him and the curse is broken which doesn't happen, making the audience think that Aurora will sleep forever. Before leaving to return to the woods, Maleficent leans over Aurora and plants a farewell kiss on her brow which makes Aurora rise from her sleep and the kiss resulting in true love's kiss. (Lane, 2014)

\section{METHODOLOGY}

The researcher will adopt Kevin Paul Smith's method of analyzing intertextual elements which he has mentioned in his book The Postmodern Fairytale, Folkloric Intertexts in Contemporary Fiction. Smith has used eight elements for intertextual analysis of any work. He proposes this theory because he believes that if we start collecting intertextual links of fairy tales in contemporary fiction, the list would be unending that's why a compact and contained framework is needed, he also adds that the postmodern writers have used the theory of Intertextuality in a particular manner and to bring out certain characteristics of fairy tales, he, in order to study those particular features, uses these eight elements of Intertextuality. These elements according to Smith do not occur alone in a text, however, it is not necessary that all the eight elements are present in a text, one of the reasons may be the fact that some of these elements are closely related to one another, there is only a difference of degree among them. (2007,p 9-57) This particular framework is used because the main concern of Smith is hypertextuality which is defined as "a field of literary works the generic essence of which lies in their relation to previous works' (Allen, 2000, 108)

While the researcher is working particularly on intertextual links present in fairy tales, this methodological framework provides the most appropriate one for the study. He mentions eight categories in which a fairy tale can be intertextually analyzed:

\subsection{Authorized}

Explicit reference to a fairytale in the title

The very first element is of authorization which is an explicit reference to a fairytale in the title. This element can be traced when evidently the exact title of the previous version is seen in the present version and the audience relate immediately to it. Almost all the fairy tales are known by their previous titles creating a clear connection with the present one.

\subsection{Writerly}

Implicit reference to a fairy tale in title

Writerly is different from authorization in matters of degree only. It is an intertextual element which can be indirectly linked to the previous versions. It is an element which can be traced when an indirect reference to an earlier fairy tale is given, when the new tale does not merely repeat the title of the older text rather makes some amendments and uses a minor character or an object present in the tale as the title. It can also be traced in "A (named) fairy tale epigraph, a foreword by the author that mentions a fairy tale, or a chapter title that refers to a fairy tale act....".(Smith, 2007, p16) 


\subsection{Incorporation}

Explicit reference to a fairy tale within the text.

The element of incorporation is a clear reference to a previous text in the present text. It is an element which embeds the old story into the new story. The postmodern writers often use this tool of incorporation to reveal the new perspectives of the characters and the writer too.

\subsection{Allusion}

Implicit reference to a fairy tale within the text

Allusion is one of the very old concepts present in Criticism but it is only recently that it is being added as an intertextual element. It refers to quotations character names, their descriptions, patterns of structures and patterns of motifs present in fairy tales. It also includes the hidden symbols. It is like the unconscious of the texts, texts or stories can have hidden meaning. Indeed, the idea of the intertext owes a great deal to the absorption of Freudian theory into everyday thought. Just as the hidden meaning of dreams may be uncovered through a careful examination of "condensation and displacement", so critics argue that a text's 'real' meaning can be discovered through the same techniques.

Freud, in his analysis of dreams, argued that they tend to focus through condensation and displacement. In condensation one sign collects into itself a host of meanings or signifiers; in displacement, a sign from another area of signification stands in for the real content of the dream. A ring in a dream might symbolically condense ideas and desires concerning a host of aspects of life: marriage, religious faith sexual desire, economic stability or instability. Condensation and displacement can, then, be seen as two operations in the semiotic process. (Allen 2000: 52-3)

\subsection{Re-vision}

\section{Putting a new spin on an old tale}

Another intertextual element is the element of Re-vision in the text. It means putting a new spin on old ones. Smith puts re-vision as the element which "covers texts where the hypertext is mainly concerned with revising the hypotext with all that this infers in terms of structural similarities between the two tales." These re-visions are usually done to remove the patriarchal authority from the texts and bring the women in the text to a more powerful position. (2007,p 34)

\subsection{Fabulation}

Crafting an original fairy tale

Fabulation is an element which is also sparsely used by the postmodernists. It is used to create an entirely new story while taking drafts of older fairy tales. The elements of fairy tale genre are present but the exact plot and structure of the previous tale are not followed while adopting the element of fabulation.

\subsection{Metafictional}

Discussion of fairy tales

Metafictional intertextuality occurs when a fairy tale is commented upon, or when the fairy tale is analyzed in a critical way. This type of intertextuality can be related to a specific tale, therefore making a close link between hypertext and hypotext. It is one of the most important tools of Postmodernists.

\subsection{Architextual/ Chronotopic}

\section{'Fairy tale' setting/environment}

This element of intertextuality does not refer back to any particular fairy tale rather it is used when fairy tale like qualities are found in the contemporary fiction. It is invoked whenever particular dramatis personae, magical events and indefinite place and time occur in a contemporary fiction.

\section{RESULTS}

An analysis of movie "Maleficent" on these elements of intertextuality highlights post-modernist characteristics present in the movie.

\subsection{Authorized}

The title plays a very important role in understanding a story line. The title of the movie "Maleficent" produced 
in 2014 is the name of the evil fairy in the fairytale of "The sleeping beauty". Although the name Maleficent was given in 1959 version of the movie the character Maleficent was always present in the tale, she was the antagonist who makes the story roll on. When In 2014 Disney's Movie, (Joe \& Robert, 2014) the title is given to the negative character, it is evident that here the movie makers are somewhat turning the movie in a new direction. In 2014 Maleficent carries the story with her too but she is no more an antagonist, not in the eyes of a postmodernist audience because here the audience gets to see the world through an open outlook. Maleficent vows to take revenge but she can't. She is not evil by nature, writer highlights the fact that nobody is evil by nature but the circumstances lead one to. Stefan, the country boy turned into a king is also not evil originally, it is only his lust for power that makes him blind towards his own good and he cuts away Maleficent's wings.

One can see the trailer of Maleficent where it is evident that this movie belongs to "Sleeping Beauty", The iconic dialogues of Sleeping Beauty which are oft repeated in almost all the versions are shown in the trailer, the scene where Maleficent curses the Princess is shown in the trailer, leaving no doubt for the audience that it is a version of "Sleeping Beauty".

\subsection{Incorporation}

The element of Incorporation which is an explicit reference to a fairy tale within the text can be used to analyze "Maleficent", the audience can hear a speaker in the background of the movie, who tells the story of Maleficent, which we later find out to be Princess Aurora herself. She explicitly mentions that this is the old story of the sleeping beauty told anew, She shows that side of the story to the readers and audience which has always remained unknown, the reason that turns a carefree fairy girl, Maleficent into a vengeful sorceress.

"Let us tell an old story anew. And we will see how well you know it. Once upon a time, there were two kingdoms that were the worst of neighbors. So vast the discord between them that is was said only a great hero or a terrible villain might bring them together. In one kingdom lived folk like you and me with a vain and greedy king to rule over them. They were forever discontent and envious of the wealth and beauty of their neighbors. For in the other kingdom, the Moors lived every manner of strange and wonderful creature. And they needed neither king nor queen but trusted in one another. In a great tree on a great cliff in the Moors lived one such spirit, you might take her for a girl, But she was not just any girl. She was a fairy, there you go and her name was Maleficent" (Joe \& Robert, 2014)

The element of incorporation is evident in the trailer of the movie as well, when it comes on the screen that "You know the title now find out the truth" it shows a clear message that there is more to the story which is otherwise known to all and that there is another angle of the story, a postmodernist angle.

\subsection{Allusion}

Implicit reference to a fairy tale within the text

\subsubsection{Quotations}

Quotations are the most obvious intertext as some of the statements or dialogues of characters are so often repeated that they have an iconic position

When the trailer of Maleficent was released it was mostly about Maleficent the fairy, and audience comes across with the dialogue of Maleficent

"Before the sun sets on her sixteenth birthday she will prick her finger on the spindle of a spinning wheel and fall into a sleep like death", (Joe \& Robert, 2014) the same dialogue repeated in almost all the narrations of the story.

\subsubsection{Character Names}

An illusory character name is an example of an intertextual reference that can be located on the surface of the text, this type of allusion is very clear, as the reader /audience recognizes the name also used in another text. Character names are same as in the original Story, only Maleficent name was given to the witch in the later versions. Aurora. Prince Philip, the former protagonists of the story carry the same names.

\subsubsection{Character descriptions}

Character descriptions often carry more importance in fairy tales than the character names because mostly the characters of fairy tales are known for their actions or particular features that make a very important aspect of the story. Sleeping Beauty also holds a distinct position, which makes her being called the Sleeping Beauty and most of its readers might not even know her real name, Aurora. 
Black and dark dress of Maleficent is enough to recognize her as the evil witch and the wrongdoer, King Stefan's innocent and grim some face while the princess was cursed is enough to send a signal to the audience that he is the good one who has been wronged.

\subsubsection{Patterns or Motifs}

Metal ring, as shown in the movie has a strong symbolic effect, in the very beginning, Stefan's ring can be seen burning Maleficent, it not only hints upon the materialism and indulging in anti-natural things, but it also indicates that Stefan will harm Maleficent in future, as Industrialism had hurt the production of natural commodities. Stefan then takes the support of same iron in preventing Maleficent coming close to him by creating walls of metal. (Joe \& Robert, 2014)

Black, again a very strong and potent symbol, has developed an archetypical place as a symbol of bad luck and evil but here again, Maleficent is not in need of support by any color, she with her black attire, has all her goodness in her, declining all the claims of past that black is a symbol of evil.

Crow which is not only having black as an indication of evil but its being is also a symbol of bad luck, crow was never mentioned as a symbol of peace or purity like pigeon, is there any evidence in the past that crow instigated world wars or lead to the death of humanity, indeed not, it is all hearsay. Postmodernists give a distinct position to Dival, who is converted into a crow, the crow does not convey any evil message to Maleficent, in fact, he always brings in news of goodness and wellbeing, like the news of the birth of princess Aurora. (Joe \& Robert, 2014)

Smith highlights this point in his analysis of Freud's theory of condensation and displacement which he compares in his procedure of intertextual analysis to the hidden meaning of the text. Many symbols or trivial incidents can be linked to repressed thoughts. (qtd. in Smith, 33) Metal ring, crow, and many other symbols were integrated into the movie in such a manner that they were not direct modes of meaning but were condensed to form a meaning.

\subsection{Re-vision}

In Fairy Tale as Myth: Myth as Fairy Tale, Zipes proposes a definition of re-vision:

'To go over again, re-examine, in order to improve or amend.' He adds that "The purpose of producing a revised fairy tale is to create something new that incorporates the critical and creative thinking of the producer and corresponds to changing demands and tastes of audiences. As a result of transformed values, the revised classical fairy tale seeks to alter the reader's views of traditional patterns, images, and codes.

(2013, p.9)

Woolverton has also revised the original tale according to the taste of a postmodernist audience. The story is same with a little twist, characters are the original ones but the outlook towards the world is different. The characters are looked upon through a different lens. King Stefan is turned into an antagonist by his own daughter, as she is the one who is narrating the story. Maleficent is shown as a powerful yet effeminate character, which was missing in the original version where her powers were only used for evilness and there was no feminine side of her character. The writer here gives credit and authority to the characters who were marginalized previously, Princess Aurora who is the Protagonist of the story and who has the honor of bagging the title of almost all the previous versions of the story, was never given a voice or a point of view, in fact in the previous versions she was treated so badly that feminists today would raise a voice against the wrongs done to her. She was raped while she was sleeping in Basile's version of the story, it would not be called a fairy tale or a love story in present times.

Maleficent in the revised version not only owns the title of the movie but also has her complete authority on the whole movie. The movie makers do not change her attire from black to more feminine color, her facial expressions are not turned soft, to make her feel wanted or loved, in fact, she with her high cheekbones looks exactly what an evil witch is, as prescribed in the minds. This points out the postmodernist way of thinking, that black color is not the color of evil, an evil face is not the symbol of the evil soul, generalizing things and categorizing them is not correct.

"True Love's Kiss" holds a very strong position in the story as that is the only moment when the princess is awakened from her deep slumber, and it always happens with a Prince falling in love with the beauty of the Princess, as if she possesses no other quality, and it is never asked, whether she accepts the love of the Prince or not. Here though Woolverton has no such desire to show to her postmodernist audience, She gives the power of true love' kiss to a female character, Maleficent who loves Aurora selflessly because she has spent all her childhood with Maleficent, they both know each other, it can be named a motherly love or any humanly developed affection, but it is not necessarily an affection of a Prince which turns the Princess, or 
IJASOS- International E-Journal of Advances in Social Sciences, Vol. III, Issue 8, August 2017

particularly a woman in a subordinate position. Thus, Aurora awakens as soon as she is kissed on her forehead by Maleficent. (Joe \& Robert, 2014)

\subsection{Metafiction}

In Maleficent, the story is narrated by Princess Aurora who clearly mentions that this is a story about a story, and explicitly mentioning all the incidents, leaving no doubts in the minds of the audience. She says,

"Our Kingdoms have been unified, you have your Queen so you see, the story is not quite as you were told, and I should know. For I was the one they called Sleeping Beauty. In the end, my kingdom was united not by a hero or a villain as legend had predicted but one who was both hero and villain and her name was Maleficent." (Joe \& Robert, 2014)

Through the use of metafiction writers try to connect the events of an original fairytale with the present, related or more realistic events which not only create metafiction of postmodernism but also emphasize on the philosophical aspect of the story in real life. The writer through the dialogues delivered by Aurora reveals that her story was always prejudiced and biased on behalf of narrators and the appearance is not necessarily the real image of anyone. Maleficent though by her looks, by her presentation looked evil, her smile was evil, her black color was a symbol of evil, her companion crow was a symbol of bad luck. A postmodernist narrator is actually conveying to the readers/audience that evil is a part of nature, some overcome the evil in themselves and some are overpowered by it, like Maleficent overcame it by trying to undo her curse on Aurora and Stefan was overpowered by it and suffered throughout his life for the lust of power which he couldn't enjoy.

Women are no more presented as decoration pieces and are not always in need of a man, a prince to be rescued, chivalry is not a symbol of masculinity and fairness is not only a characteristic of females but it can be related to anyone at any time. Thus, Intertextuality changed the understanding of the original story, destabilized the prior school of thought and reversed the positions by giving voice to females and positive image to black color and the crow.

\section{CONCLUSION}

Maleficent has very evident traces of postmodernism. These aspects of postmodernism present in the contemporary American fairy tale movie, Maleficent highlight the rejection of totality. It goes against the meta-narratives and highlights the pluralist point of view. The idealistic notion of fairy tales presenting the females as passive characters, waiting to be loved and rescued by prospectus Prince is rejected here because Princess Aurora does not wake up by the kiss of Prince, rather she wakes up by the kiss of Maleficent. She was previously the antagonist in the older versions. The characteristic of rejecting the totalitarian perspective of a witch being evil and harmful is altered here. She had been a marginalized character to because her perspective and opinion was never taken, she was only presented as evil. This aspect is also altered because postmodernists believe in giving voice to every unheard character. Thus through the intertextual elements, the researcher has highlighted the postmodernist aims propagated by the fore mentioned school of thought.

By rewriting, altering and changing the motifs, a version is brought forward which is not typical and conventional as depicted in the past through traditional narrative techniques. On the level of the text, it not only gives a positive image to the negative characters but it also takes different perceptive on the narration of the story. Maleficent, the witch, has always been rebuked and stamped as a negative character because that was how she was represented but then came the postmodernists, who challenged the perception of their predecessors. They showed the world in the shape of 'Maleficent' movie and many other revisions of fairy tales that truth is always not what we believe, it can be contrary to it. Woolverton here narrated the story through Princess Aurora to give an unbiased perception. In Maleficent, this change in conventionality is not only represented through narration but it is also portrayed through changing the symbols. Maleficent breaks the shackles of stereotype. Black has always been represented as a symbol of evil and gloom but here writer gives the same black to a preconceived evil character "Maleficent", but turns the concept created in everyone's mind by changing the Maleficent into a benevolent character. Crow is always symbolized as a bad omen and ugly too but here the crow is loved by Aurora. This alternative is aimed to create "relativization", they offer an alternative reconsideration of past and creating awareness in the process of representation.

This research shows some strong implications for future research. The framework for scrutinizing the fairy tales on the basis of intertextuality paves ways for conducting research from different angles based on the same framework provided by Kevin Paul Smith in his Book The Postmodern Fairytale, Folkloric Intertexts in Contemporary Fiction. Examination of postmodernist trends also opens up scrutiny of the films to highlight 
how these alterations in their stories are affecting the audience.

\section{ACKNOWLEDGEMENT}

This Research project could not have been completed without the financial and moral support of Higher Education Commission of Pakistan, specifically the Indigenous HEC fellowship program, and the research grant initiative by HEC. Special thanks to my supervisor Dr. Bahramand Shah who never put a stop to my imaginative traits, last but not the least special thanks to my Mentor Dr. Muhammad Islam, Dean lqra University, Islamabad, my Department's Director Dr. Noman Sattar and my Research Mentor Dr. Maria Staton from Ball State University. Special thanks to Sardar Bahadur Khan Women's University, Quetta, for nurturing my abilities, making me a confident researcher and a responsible human being.

\section{REFERENCE LIST}

Allen, G. (2000). Intertextuality. London and New York: Routledge

Bacchilega, C.(1999). Postmodern Fairy Tales: Gender and Narrative Strategies.Philadelphia: University of Pennsylvania press.

Baer, E. R. (2005) A Postmodern fairy tale of the Holocaust: Jane Yolen's "Briar Rose". Studies in American Jewish Literature, 24.145-152 Retrieved 24-10-2014 http://www.jstor.org/stable/41206033?origin=JSTOR-pdf

Barry, P.(2008). Beginning Theory: An Introduction to Literary and Cultural Theory. New Delhi: Viva Books

Barthes, R. (1977). Image-Music-Text. Translated by Stephen Heath. London: Fontana

Benson, S.(2008.)Contemporary Fiction And The Fairy Tale. Michigan: Wayne State University Press.

Crews, B.(1999). "Postmodernist narrative: In search of an alternative." Alicante Journal of English Studies. 12 19-36.

Cuddon, J A.(1999). The Penguin Dictionary of Literary Terms and Literary Theory. England: Penguin Books.

Cuddon, J A.(2000). The Penguin Dictionary of Literary Terms and Literary Theory. England: Penguin Books.

Joe, R. (Producer) \& Robert, S (Director). (2014). Maleficent. [ Motion Picture]. USA: Walt Disney Pictures

Jorgenson, J. (2007). "A wave of the magic wand: Fairy Godmothers in Contemporary American Media." Marvels \& Tales, 21(2) 216-227

Kristeva, J,(1986).Word, Dialogue, and Novel., In Moi, Toril, ed, The Kristeva Reader. ,34-37.

Lane, A.(2014,Nov 4) Tales Retold. The NewYorker Times. Retrieved from http://www.newyorker.com/magazine/2014/06/09/tales-retold

Lyotard, J. F.(1984) "Answering the Question: What is Postmodernism" Tran. Geoff Bennington and Brian Massumi. The Postmodern Condition: A Report on Knowledge

Pokrivcak, A, and Silvia P. (2006). Understanding Literature. Brno: MSD. Print

Sharma, R., and Preety, C. (2011) "Common themes and techniques of Postmodern."International Journal of Educational Planning \& Administration. 1(2) 189-198.

Smith, K.P. (2007) The Postmodern Fairy Tale: Folkloric Intertexts in Contemporary Fiction. NewYork: Palgrave Macmillan

Tatar, M. (2002). The Annotated Classic Fairy Tales. New York: Norton.

The Sleeping Beauty. (1873). The Sleeping Beauty. The Aldine, 6(9), 184-185. Retrieved from http://www.jstor.org/stable/20636611

Yaqoob, M. \& Saira, S. (2012). Kamila Shamsie's Burnt Shadows as an intertextual re-writing of Forster's Passage to India. Academic Research International, 2 (1) 478

Zipes, J.(2013) Fairy Tale as Myth/Myth as Fairy Tale. Lexington: The University Press of Kentucky 